\title{
Prenatal diagnosis of ornithine transcarbamylase deficiency: optimizing pregnancy outcome in a woman with previous affected babies
}

\author{
Chandana Galidevara ${ }^{1 *}$, Swaramya Chandrasekaran ${ }^{2}$
}

\begin{abstract}
${ }^{1}$ Department of Obstetrics and Gynecology, Mahatma Gandhi Medical College and Research Institute, Puducherry, India

${ }^{2}$ Department of Obstetrics and Gynaecology, Indira Gandhi Medical College and Research Institute, Puducherry, India
\end{abstract}

Received: 06 January 2018

Accepted: 09 January 2018

*Correspondence:

Dr. Chandana Galidevara,

E-mail: galichandana@gmail.com

Copyright: ( ) the author(s), publisher and licensee Medip Academy. This is an open-access article distributed under the terms of the Creative Commons Attribution Non-Commercial License, which permits unrestricted non-commercial use, distribution, and reproduction in any medium, provided the original work is properly cited.

\begin{abstract}
Ornithine Transcarbamylase (OTC) deficiency is an inherited X-linked disorder which predominantly affects males. Females are usually carriers and may rarely be symptomatic. Affected individuals may present with severe life threatening disease immediately after birth. Those with variants of the disease may have late adult onset symptoms. We report a case of an asymptomatic female heterozygous carrier of the defect with recurrent poor obstetric outcomes and subsequent management with prenatal diagnostic testing.
\end{abstract}

Keywords: Amniocentesis, Ornithine transcarbamylase deficiency, Prenatal diagnosis, Urea cycle disorder

\section{INTRODUCTION}

Ornithine Transcarbamylase (OTC) deficiency is a rare inborn error of metabolism involving the urea cycle. It is an X-linked recessive disorder wherein the males present with severe, life threatening disease form. Given the dismal prognosis and neurological sequelae in affected babies, timely prenatal evaluation of at risk foetuses and instituting appropriate measures is crucial for optimising pregnancy outcomes. We report a case of an asymptomatic female heterozygous carrier of the defect with recurrent poor obstetric outcomes and subsequent management with prenatal diagnostic testing.

\section{CASE REPORT}

A 26-year-old woman presented with her sixth pregnancy. She had her first pregnancy five years back which resulted in a term intrauterine fetal demise. Her second pregnancy was a missed abortion at 2 months. Her third pregnancy was four years back and she delivered a vigorous male baby weighing $3.6 \mathrm{~kg}$. On day three of life, the baby became less active, had feeding difficulties and had refractory seizures. The baby expired on fourth day of postnatal life.

The patient had her fourth pregnancy three years back. She had a spontaneous vaginal delivery resulting in a male baby weighing $3.2 \mathrm{~kg}$ with similar postnatal course as the previous baby. A workup to look for metabolic disorders was undertaken. Newborn screening of blood by tandem mass spectroscopy revealed elevated levels of proline, methionine, tyrosine, phenylalanine and alanine and low levels of citrulline. The acyl carnithine levels in blood were normal (Table 1).

An initial differential diagnosis of carbamoylphosphate synthetase-1 deficiency and ornithine transcarbamylase deficiency was made. A further analysis of urine organic acids by gas chromatography and mass spectrometry revealed an elevation of orotic acid and uracil (Table 2). Therefore, the baby was diagnosed to have ornithine 
transcarbamylase deficiency which is a disorder of urea cycle metabolism.

Table 1: Tandem mass spectroscopy of newborn screening for blood amino acids.

\begin{tabular}{|lll|}
\hline Analyte & Conc $(\mu \mathrm{M})$ & Reference range $(\mu \mathrm{M})$ \\
\hline Proline & $713.8(\uparrow)$ & $87-381$ \\
\hline Valine & 181.2 & $52-322$ \\
\hline Leucine & 252 & $27-324$ \\
\hline Methionine & $67.7(\uparrow)$ & $5-37$ \\
\hline Phenylalanine & $82(\uparrow)$ & $10-77$ \\
\hline Tyrosine & $269(\uparrow)$ & $15-111$ \\
\hline Citrulline & $3.1(\downarrow)$ & $6-43$ \\
\hline Ornithine & 142.9 & $36-164$ \\
\hline Arginine & 17.1 & $2-41$ \\
\hline Glycine & 651 & $0-800$ \\
\hline Alanine & $5053.5(\uparrow)$ & $103-742$ \\
\hline
\end{tabular}

The mother's genetic testing of OTC gene by Sanger sequencing revealed a heterozygous carrier state for the missense mutation c.275G (p.R92P) in exon 2 which is a known pathological variant for this particular urea cycle disorder. The woman had been asymptomatic with no history of hyperammonemic crisis so far.

The woman had her fifth pregnancy two years back. She opted for prenatal diagnosis at 16 weeks, hence an early target scan to look for major anomalies was done followed by amniocentesis. The amniotic fluid was sent for targeted genetic testing which revealed a homozygous state for the mutation in OTC gene. As the fetus was affected by the disorder, the woman opted for pregnancy termination at 18 weeks.

During her sixth pregnancy, amniocentesis was performed at 16 weeks and the gene testing of the fetus showed no mutation in the OTC gene. A detailed anomaly scan was done at 5 month which was normal. At 38 weeks the patient had spontaneous labour pains and delivered vaginally. A healthy male baby weighing $2.9 \mathrm{~kg}$ with 9/10 Apgar was born. The newborn screening for the baby was normal and the baby is currently doing well.

Table 2: Gas chromatography/mass spectrometry report of elevated urine organic acids.

\begin{tabular}{|c|c|c|c|c|c|}
\hline \multirow{2}{*}{$\begin{array}{l}\text { Compound } \\
\text { name }\end{array}$} & \multicolumn{4}{|c|}{$\begin{array}{l}\text { Relative peak area of compound with respect to internal standard- } \\
\text { Margaric acid }\end{array}$} & \\
\hline & Result & Cut off & Reference range & Fold elevation & \\
\hline Orotic -3 & $36.5 \%$ & $2.5 \%$ & $0 \%-1.5 \%$ & 24.35 & Moderate elevation \\
\hline Uracil -2 & $23.9 \%$ & $19.6 \%$ & $0 \%-7 \%$ & 3.42 & Mild elevation \\
\hline
\end{tabular}

\section{DISCUSSION}

OTC deficiency occurs at a frequency of $1 / 80000$ $1 / 50000$, though accurate estimates are elusive owing to the rarity of these urea cycle defects and their underdiagnosis. ${ }^{1}$ Being an $\mathrm{X}$ - linked recessive disorder, males have a preponderance for more severe forms of the disease. Affected neonates may initially have symptoms of poor feeding, vomiting, incessant crying and irritability, which may rapidly progress to hypotonia, seizures and eventually, if untreated, may result in profound neurological sequelae and even death. ${ }^{2}$

Females who are heterozygous for the defect are carriers who are seldom symptomatic. A small subset of affected females, who eventually manifest with the disease present most often with mild symptoms and rarely suffer from severe illness during childhood.

A variant of OTC deficiency can manifest with late onset of symptoms triggered by stressors leading to a spectrum of symptoms ranging from recurrent headaches to a full blown lethal hyperammonemic crisis. There have also been rare instances of deterioration and accelerated hyperammonemic coma during pregnancy. ${ }^{3}$ Our patient had an uncomplicated antenatal and intrapartum course through all her pregnancies and did not manifest with any symptoms suggestive of her being a heterozygous carrier for the affected gene.

The diagnosis of OTC deficiency involves serum ammonia levels measuring more than $2000 \mathrm{mg} / \mathrm{dL}$ and elevated levels of ornithine, glutamine and alanine levels with relative low citrulline levels. This is associated with increased levels of urinary orotic acid. ${ }^{4}$

Screening of a previously affected newborn clinched the diagnosis of OTC deficiency as a cause for the recurrent neonatal deaths, which led to genetic testing and detection of carrier state in the mother. This paved the way for targeted prenatal diagnosis in her subsequent pregnancies and optimised the outcome for the currently alive and healthy baby.

\section{CONCLUSION}

A high index of suspicion for inborn errors of metabolism is the key to appropriate evaluation, diagnosis and management of the affected new-born. Of more significance, is evaluating the couple for gene defects and 
offering genetic counselling for future pregnancies. Prenatal diagnosis by amniocentesis can help in appropriate management of the ongoing pregnancy and hence optimise the outcomes.

Funding: No funding sources Conflict of interest: None declared

Ethical approval: Not required

\section{REFERENCES}

1. National organisation for rare disorders - ornithine transcarbamylase deficiency. Available at https://rarediseases.org/rare-diseases/ornithinetranscarbamylase-deficiency

2. Genetics Home Reference. ornithine transcarbamylase deficiency. Reviewed June 2006. Available https://ghr.nlm.nih.gov/condition/ornithine- transcarbamylase-deficiency. Accessed ON December 13, 2016.

3. Lamb S, Aye CYL, Murphy E, Mackillop L. Multidisciplinary management of ornithine transcarbamylase (OTC) deficiency in pregnancy: essential to prevent hyperammonemic complications. BMJ Case Reports. 2013 Jan;2013:bcr2012007416.

4. Roth KS. Ornithine Transcarbamylsae deficiency. medscape. Last Update August 28, 2015. Available at http://emedicine.medscape.com/article/950672overview Accessed on December 13, 2016.

Cite this article as: Galidevara C, Chandrasekaran S. Prenatal diagnosis of ornithine transcarbamylase deficiency: optimising pregnancy outcome in a woman with previous affected babies. Int J Reprod Contracept Obstet Gynecol 2018;7:742-4. 